\title{
Bigelovin inhibits STAT3 signaling by inactivating JAK2 and induces apoptosis in human cancer cells
}

\author{
Hao-hao ZHANG ${ }^{1, \#}$, Shan KUANG ${ }^{1, \#}$, Ying $W_{A N G}{ }^{1}$, Xiao-xiao SUN ${ }^{1}$, Yuan GU ${ }^{1}$, Li-hong HU², Qiang YU ${ }^{1, *}$ \\ ${ }^{1}$ Department of Tumor Pharmacology, Shanghai Institute of Materia Medica, Chinese Academy of Sciences, Shanghai 201203, China; \\ ${ }^{2}$ State Key Laboratory of Drug Research, Shanghai Institute of Materia Medica, Chinese Academy of Sciences, Shanghai 201203, \\ China
}

Aim: To study the function and mechanism of bigelovin, a sesquiterpene lactone from the flower of Chinese herb Inula hupehensis, in regulating JAK2/STAT3 signaling and cancer cell growth.

Methods: HepG2 cells stably transfected with the STAT3-responsive firefly luciferase reporter plasmid (HepG2/STAT3 cells), and a panel of human cancer cell lines were used to identify active compounds. Cell viability was measured using MTT assay. Western blotting was used to detect protein expression and phosphorylation. Kinase assays were performed and the reaction between bigelovin and thiolcontaining compounds was analyzed with LC-MS.

Results: Bigelovin (1-50 $\mu \mathrm{mol} / \mathrm{L})$ dose-dependently inhibited the IL-6-induced STAT3 activation in HepG2/STAT3 cells $\left(\mathrm{IC}_{50}=3.37 \mu \mathrm{mol} / \mathrm{L}\right)$ and the constitutive STAT3 activation in A549 and MDA-MB-468 cells. Furthermore, bigelovin dose-dependently inhibited JAK2 phosphorylation in HeLa and MDA-MB-468 cells, as well as the enzymatic activity of JAK2 in vitro $\left(\mathrm{IC}_{50}=44.24 \mu \mathrm{mol} / \mathrm{L}\right)$. Pretreatment of the cells with DTT $(500 \mu \mathrm{mol} / \mathrm{L})$ or GSH $(500 \mu \mathrm{mol} / \mathrm{L})$ eliminated the inhibitory effects of bigelovin on the IL-6-induced and the constitutive STAT3 activation. The results in LC-MS analysis suggested that bigelovin might react with cysteine residues of JAK2 leading to inactivation of JAK2. Bigelovin ( 5 and $20 \mu \mathrm{mol} / \mathrm{L}$ ) had no effects on the signaling pathways of growth factors EGF, PDGF or insulin. Finally, bigelovin suppressed the cell viability and induced apoptosis in 10 different human cancer cell lines, particularly those with constitutively activated STAT3.

Conclusion: Bigelovin potently inhibits STAT3 signaling by inactivating JAK2, and induces apoptosis of a variety of human cancer cells in vitro.

Keywords: apoptosis; tumor cell line; Chinese herbal drugs; Inula hupehensis; neoplasms; STAT3 transcription factors; Janus kinase 2; DTT; signal transduction; bigelovin; interleukin-6; sesquiterpenes

Acta Pharmacologica Sinica (2015) 36: 507-516; doi: 10.1038/aps.2014.143; published online 26 Jan 2015

\section{Introduction}

The Inula flower, used as a well-known traditional herbal medicine, is widely found in Europe, Asia and Africa ${ }^{[1]}$. More than 20 species of the genus Inula are found in China, many of which have long been used in traditional Chinese medicine to treat inflammation and cancer. Diversified biological activities have been reported to account for the many applications of Inula, including antioxidant activity, modulation of inflammatory molecules such as iNOS and cyclooxygenase-2, and hepatoprotective activity ${ }^{[2,3]}$. Bigelovin, a sesquiterpene lactone isolated from the flowers of Inula hupehensis, has been

\footnotetext{
\#These authors contributed equally to this work.

* To whom correspondence should be addressed.

E-mail qyu@sibs.ac.cn

Received 2014-10-27 Accepted 2014-11-27
}

shown to have anticancer activity ${ }^{[4,5]}$. However, few studies have revealed its mode of action, and the molecular targets of bigelovin have not been identified.

The Janus kinase (JAK) and signal transducer and activator of transcription (STAT) pathway is responsible for signal transduction of a large number of cytokines and mediates many important physiological functions in immune modulation, inflammation, cell proliferation, differentiation, development, cell survival and apoptosis ${ }^{[6,7]}$. After the cytokines bind to their cognate receptors, the JAKs are activated and proceed to phosphorylate the STATs. The phosphorylated STATs then form homodimers or heterodimers via reciprocal phosphotyrosine-SH2 domain interactions and translocate into the nucleus to regulate the expression of target genes ${ }^{[8-10]}$.

Constitutive activation of the JAK/STAT pathway, particularly those in which STAT3 is involved, is frequently associ- 
ated with cancer ${ }^{[11,12]}$. It has been well established that STAT3 acts as an oncogene ${ }^{[13]}$. The constitutive activation of STAT3 has been found to be required for tumor growth and survival in many human cancers (including breast, pancreatic, ovarian, head and neck, brain, and prostate carcinomas, as well as in melanoma, leukemia and lymphoma $)^{[14-21]}$, and blocking the aberrant activation of STAT3 results in inhibition of tumor growth and survival and the induction of apoptosis with few side effects in normal cells. JAKs are also frequently found to be activated in cancer and other proliferative diseases. JAK2 involvement in oncogenesis has been thoroughly studied ${ }^{[22]}$. For example, abnormal translocation involving genes in the JAK2 pathway have been implicated in the pathogenesis of leukemia and other hematologic malignancies in humans ${ }^{[23-25]}$. Abnormal fusion proteins, such as TEL-JAK2 and PCM1JAK2, resulting from such translocations usually cause constitutive activation of JAK2 as well as its downstream signal pathway ${ }^{[24,25]}$. Additionally, an activating mutation in JAK2 (V617F) is found in the majority of patients with polycythemia vera and with other myeloproliferative disorders, such as essential thrombocythemia and idiopathic myelofibrosis ${ }^{[26-28]}$.

Given the importance of the JAK2/STAT3 signaling pathway in cancer development, the identification of inhibitors of this pathway has received considerable interest. Here, we identified bigelovin as a potent inhibitor of the JAK2/STAT3 signaling pathway that functions by inactivating JAK2. The effects of bigelovin on the JAK2/STAT3 pathway are relatively specific. It did not affect many other growth factor signaling pathways. Furthermore, bigelovin inhibited growth and induced tumor cell apoptosis with selectivity towards those with constitutively activated STAT3. Our data provide a possible mechanism for the anti-tumor activity of bigelovin and support its promise as a potential anticancer drug candidate.

\section{Materials and methods Reagents and antibodies}

Bigelovin (purity $>99 \%$ ), isolated from the inflorescence of Inula hupehensis, was provided by Dr Li-hong HU. Dithiothreitol (DTT), and 3-(4,5-dimethylthiazol-2-yl)-2,5-diphenyltetrazolium bromide (MTT) were purchased from Genebase (Shanghai, China). Recombinant human interleukin(IL)-6 was purchased from Sigma-Aldrich (Saint Louis, MO, USA). Recombinant human EGF was purchased from Biosource (Camarillo, CA, USA). Annexin V-FITC apoptosis detection kit was from Vazyme (Nanjing, China). The sources of antibodies were as follows: anti-phospho-STAT3 (Tyr705), anti-phospho-JAK2 (Tyr1007/1008), anti-phospho-ERK1/2 (Thr202/Tyr204), anti-phospho-IRS, anti-IRS, anti-poly(ADPribose) polymerase (PARP), anti-phospho-STAT5 (Tyr694), and anti-STAT5 (Cell Signaling Technology, Beverly, MA, USA); anti-STAT3, anti-JAK2, anti- $\alpha$-Tubulin, anti- $\beta$-actin, anti-EGFR, anti-GP130, anti-phospho-platelet-derived growth factor receptor (PDGFR, Santa Cruz Biotechnology, Dallas, TX, USA); anti-phosphotyrosine 4G10 (Upstate, Millipore, Billerica, MA, USA); anti-phospho-epidermal growth factor recep- tor (EGFR, Tyr1068, Abcam, Cambridge, UK); and secondary HRP-conjugated antibody (Jackson ImmunoResearch, West Grove, PA, USA).

\section{Cell culture}

The HepG2/GAS-luciferase cell line, in which HepG2 cells were stably transfected with a STAT3-responsive firefly luciferase reporter plasmid, was a gift from Prof Xin-yuan FU (National University of Singapore, Singapore), and all other cell lines were obtained from the American Type Culture Collection. HeLa, HEK293, A549, H460, MDA-MB-468, MDAMB-453, and MDA-MB-231 cell lines were cultured in DMEM containing $10 \%(v / v)$ fetal bovine serum (FBS, Hyclone, Logan, UT, USA); the HepG2 cell line was cultured in a-MEM containing 10\% FBS; U937, HL-60, and Jurkat cell lines were cultured in RPMI-1640 containing 10\% FBS. All the cell lines were cultured at $37^{\circ} \mathrm{C}$ in a humidified atmosphere of $5 \% \mathrm{CO}_{2}$.

\section{Luciferase assay}

HepG2/GAS-luciferase cells $\left(1.5 \times 10^{5}\right.$ per well) were seeded into 24-well cell culture microplates (Corning, Tewksbury, MA, USA) and allowed to grow for $24 \mathrm{~h}$. The cells were treated with corresponding treatments for $1 \mathrm{~h}$ followed by stimulation with $10 \mathrm{ng} / \mathrm{mL}$ IL-6 for $5 \mathrm{~h}$. Luciferase activity was determined using Promega (Madison, WI, USA) luciferase kits according to the manufacturer's instruction. Cell number was counted at the time of seeding and was controlled by equal seeding.

\section{Western blot analysis}

Whole-cell lysates were prepared in $1 \times$ Laemmli sample buffer (Sigma-Aldrich) to extract total protein. Equivalent amounts of total cellular protein were electrophoresed on an 8\% SDSPAGE gel and transferred onto nitrocellulose membranes (Millipore). Membranes were blocked in 5\% nonfat milk in TBS containing $0.1 \%$ Tween 20 (TBST) for $1 \mathrm{~h}$ at room temperature and then incubated with primary antibodies in 5\% bovine serum albumin (BSA) in TBST at $4{ }^{\circ} \mathrm{C}$ overnight. Membranes were then washed with TBST and incubated with horseradish peroxidase-conjugated secondary antibody in 5\% BSA in TBST for $1 \mathrm{~h}$ at room temperature. Immune complexes were detected by enhanced chemiluminescence (Pierce, Rockford, IL, USA).

\section{IL-6 receptor binding assay}

The inhibitory effects on the binding of IL-6 and its receptor were tested using a human IL-6 biotinylated fluorokine kit (R\&D System, Minneapolis, MN, USA) according to the manufacturer's instruction. Briefly, HeLa cells were trypsinized, centrifuged and re-suspended in culture medium. The suspended HeLa cells were then treated with dimethyl sulfoxide (DMSO, vehicle control) or $100 \mu \mathrm{mol} / \mathrm{L}$ bigelovin for $10 \mathrm{~min}$. Cells were then incubated with biotin-IL- 6 at $4^{\circ} \mathrm{C}$ for $1 \mathrm{~h}$ followed by the addition of avidin-FITC at $4^{\circ} \mathrm{C}$ for $30 \mathrm{~min}$. The intensity of fluorescence was analyzed by flow cytometry. 


\section{Co-immunoprecipitation}

Cells were harvested on ice for 30 min using RIPA buffer containing $50 \mathrm{mmol} / \mathrm{L}$ Tris (pH 7.5), 1\% NP-40, $150 \mathrm{mmol} / \mathrm{L}$ $\mathrm{NaCl}, 1 \mathrm{mmol} / \mathrm{L}$ EDTA, $1 \mathrm{mmol} / \mathrm{L}$ PMSF, $1 \mathrm{mmol} / \mathrm{L} \mathrm{Na}_{3} \mathrm{VO}_{4}$, $1 \mathrm{mmol} / \mathrm{L} \mathrm{NaF}$, and a complete protease inhibitor cocktail (Sigma-Aldrich). Cell lysates were precleared with protein A/G plus agarose (Santa Cruz Biotechnology) for $1 \mathrm{~h}$ at $4{ }^{\circ} \mathrm{C}$ followed by incubating with primary antibody at $4{ }^{\circ} \mathrm{C}$ overnight with gentle agitation and with protein $\mathrm{A} / \mathrm{G}$ plus agarose for another $2 \mathrm{~h}$. After the agarose pellets had been washed five times with RIPA buffer, bound proteins were extracted with Laemmli $2 \times$ sample buffer (Sigma-Aldrich) by heating at $100^{\circ} \mathrm{C}$ for $10 \mathrm{~min}$ and were subjected to Western blotting.

\section{Kinase assay}

The JAK2 kinase assay was performed using an HTScan JAK kinase assay kit (Cell Signaling Technology) with JAK2 immunoprecipitates. Briefly, HEK293 cells were transfected with a JAK2 expression plasmid for $24 \mathrm{~h}$ and then lysed in $50 \mathrm{mmol} / \mathrm{L}$ HEPES (pH 7.4), 0.1\% Triton X-100, $150 \mathrm{mmol} / \mathrm{L}$ $\mathrm{NaCl}, 0.5 \mathrm{mmol} / \mathrm{L} \mathrm{DTT}, 2 \mathrm{mmol} / \mathrm{L} \mathrm{Na}_{3} \mathrm{VO}_{4}, 2 \mathrm{mmol} / \mathrm{L} \mathrm{NaF}, 1$ $\mathrm{mmol} / \mathrm{L}$ PMSF, and protease inhibitor cocktail (1:1000; SigmaAldrich) on ice. Sample lysates were collected and cleared. Then, $500 \mu \mathrm{g}$ of lysates were immuno-precipitated with $400 \mathrm{ng}$ of antibodies specific for JAK 2 for $1 \mathrm{~h}$ at $4{ }^{\circ} \mathrm{C}$ and rocked with $25 \mu \mathrm{L}$ of protein A/G plus-agarose (Santa Cruz Biotechnology) overnight at $4^{\circ} \mathrm{C}$. The samples were then washed three times with lysis buffer and once with kinase reaction buffer [60 $\mathrm{mmol} / \mathrm{L} \mathrm{HEPES} \mathrm{(pH} \mathrm{7.5),} 5 \mathrm{mmol} / \mathrm{L} \mathrm{MgCl}_{2}, 5 \mathrm{mmol} / \mathrm{L} \mathrm{MnCl}_{2}$, $\left.3 \mu \mathrm{mol} / \mathrm{L} \mathrm{Na}_{3} \mathrm{VO}_{4}, 0.5 \mathrm{mmol} / \mathrm{L} \mathrm{DTT}\right]$. Then, kinase reactions were performed with the JAK2 immuno-precipitates and the HTScan JAK kinase assay kit at $30^{\circ} \mathrm{C}$ for $30 \mathrm{~min}$ in a final volume of $50 \mu \mathrm{L}$ of reaction buffer containing $20 \mu \mathrm{mol} / \mathrm{L}$ ATP and $1.5 \mu \mathrm{mol} / \mathrm{L}$ peptide substrate. Samples were pretreated with vehicle control (DMSO) or different concentrations of bigelovin before the addition of ATP. Kinase activity was measured according to the manufacturer's instruction. Other kinase assays in this paper were conducted by Millipore.

\section{Conjugation of bigelovin with glutathione}

Bigelovin $(50 \mu \mathrm{mol} / \mathrm{L})$ in DMSO was incubated with reduced glutathione $(250 \mu \mathrm{mol} / \mathrm{L})$ in PBS buffer $(\mathrm{pH} 7.4)$ at $37^{\circ} \mathrm{C}$ for $1 \mathrm{~h}$. Then, the sample was injected in the liquid chromatographymass spectrometry (LC-MS) system using acetonitrile/water (3:7) as the mobile phase at a rate of $3 \mathrm{~mL} / \mathrm{min}$, ESI-positive mode. High performance liquid chromatography analysis was performed using an Agilent HP 1100 series HPLC system (Agilent Technologies, Santa Clara, CA, USA). Mass spectrometry was recorded using a LCQ Deca ion trap mass spectrometer (ThermoFinnigan, San Jose, CA, USA).

\section{MTT analysis}

Approximately 5000 cells per well were seeded into 96-well plates. Twenty-four hours later, cells were treated with vehicle control (DMSO) or increasing concentrations of bigelovin for $72 \mathrm{~h}$. Twenty microliters of MTT $(5 \mathrm{mg} / \mathrm{mL})$ was added to the culture medium. After incubating for $3 \mathrm{~h}$ at $37^{\circ} \mathrm{C}$, the cells were solubilized in DMSO, and the absorbance of each well was measured at $570 \mathrm{~nm}$ with a spectrophotometer (Molecular Device, Sunnyvale, CA, USA).

\section{Statistical analysis}

Triplicates were performed for each experiment, and data were shown only if three independent experiments showed consistent results. All results are expressed as the mean \pm SEM. Statistical differences between groups were determined by using the unpaired Student's $t$-test. $P<0.05$ was considered statistically significant.

\section{Results}

Bigelovin inhibited IL-6-induced and constitutive STAT3 activation In an attempt to discover novel anticancer drugs from natural compounds targeting the JAK2/STAT3 signaling pathway, traditional Chinese medicinal herb extracts, which have traditionally been used to treat cancer and inflammation, were screened using an IL-6-induced STAT3-responsive luciferase reporter assay in HepG2 cells. Bigelovin (Figure 1A), a sesquiterpene lactone isolated from the flowers of Inula hupehensis, was found to strongly inhibit IL-6-induced STAT3-responsive luciferase activity in a dose-dependent manner (Figure 1B). The half maximal inhibition dose was $3.37 \mu \mathrm{mol} / \mathrm{L}$. In contrast to the inhibition of STAT3 signaling, bigelovin only slightly decreased the cell number of HepG2 cells (Figure 1C), suggesting that the inhibition effects of bigelovin on STAT3 signaling were not a result of reduced cell number. To map the action site of bigelovin along the JAK2/STAT3 signaling pathway, the effects of bigelovin on IL-6-induced STAT3 tyrosine phosphorylation, which is a prerequisite for STAT3 biological activity, were examined. Bigelovin inhibited IL-6-induced STAT3 tyrosine phosphorylation in a dose-dependent manner (Figure 1D) and completely inhibited IL-6-induced STAT3 tyrosine phosphorylation at $10 \mu \mathrm{mol} / \mathrm{L}$. Of note, the inhibition was rapid. Treatment of HeLa cells with $10 \mu \mathrm{mol} / \mathrm{L}$ bigelovin for as few as 15 min was effective (Figure 1E). Bigelovin not only inhibited IL-6-induced STAT3 phosphorylation but also exhibited similar inhibitory effects on constitutive STAT3 tyrosine phosphorylation in A549 and MDA-MB-468 tumor cells (Figure 1F). The latter two tumor cell lines have been reported to express constitutively activated STAT3, and the continued growth and survival of these cells seem to rely on STAT3 signaling ${ }^{[29,30]}$. Therefore, bigelovin inhibited both IL-6-induced and constitutive activation of STAT3.

\section{Bigelovin inhibited the kinase activity of JAK2 both in cells and in vitro}

The ability of bigelovin to suppress IL-6-induced tyrosine phosphorylation of STAT3 suggests that this agent might interfere with the upstream components of the STAT3 signaling pathway. The binding of IL-6 to its receptors will lead to IL-6 receptor and GP130 oligomerization, bringing JAK2 (the major STAT3 kinase) and GP130 closer to each other. After being juxtaposed, JAK2 is autoactivated by transphosphoryla- 
A<smiles>C=C1C(=O)O[C@H]2C[C@H](C)[C@H]3C=CC(=O)[C@]3(C)[C@H]12</smiles>
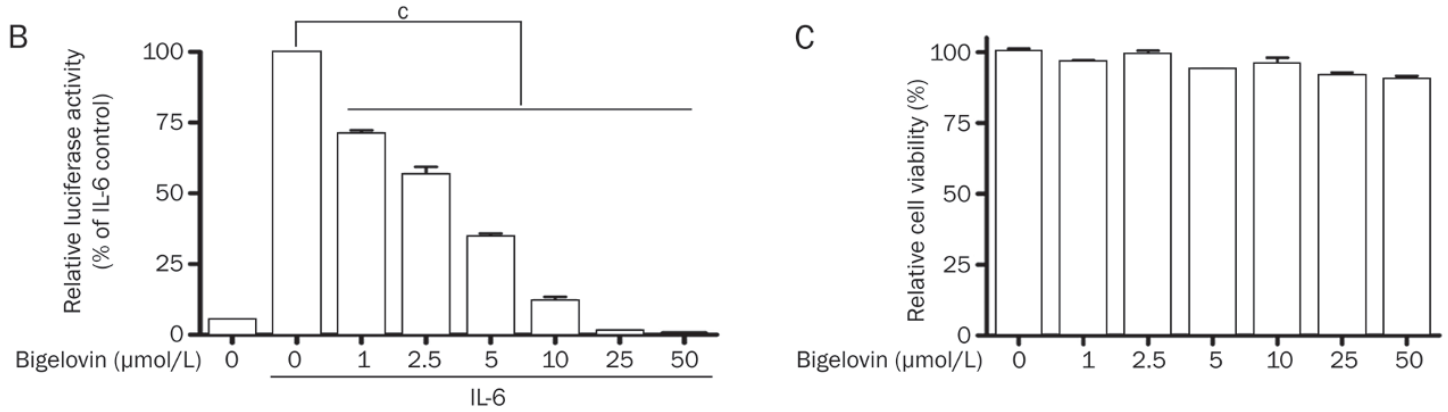

D

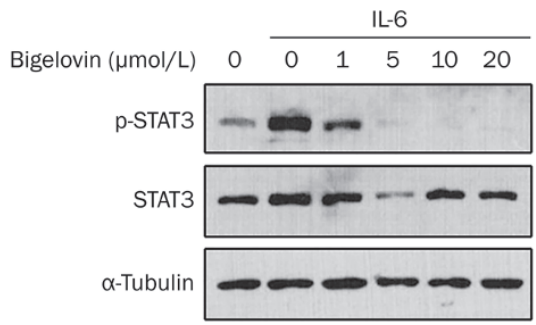

F

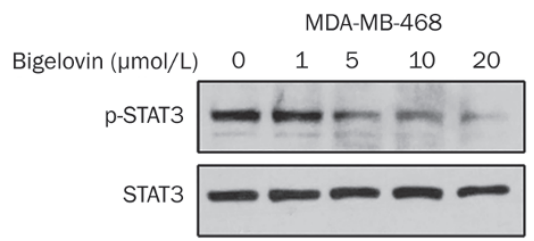

E
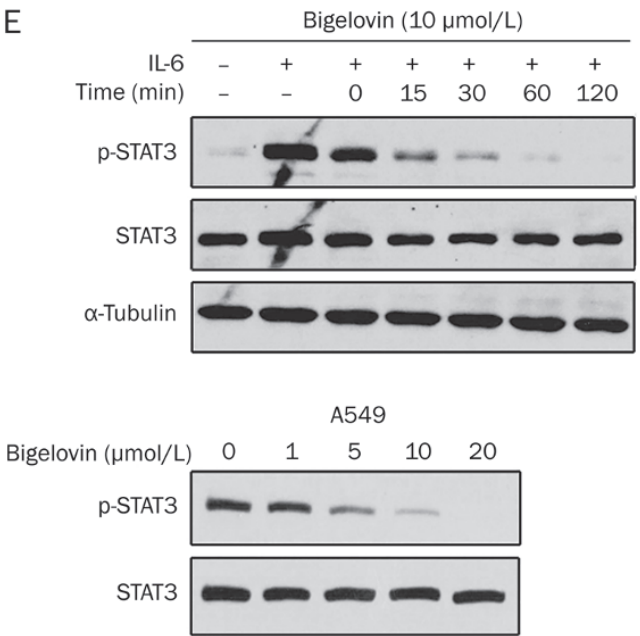

Figure 1. Bigelovin inhibited IL-6-induced and constitutive activation of STAT3 in human tumor cell lines. (A) The structure of bigelovin. (B) HepG2/ STAT3 cells were pretreated with bigelovin at the indicated concentrations for $1 \mathrm{~h}$, and luciferase activity was measured following IL-6 stimulation (20 $\mathrm{ng} / \mathrm{mL}$ ) for $5 \mathrm{~h} . \mathrm{n}=3$ experiments. Mean \pm SEM. ${ }^{\mathrm{c}} P<0.01$ vs control. (C) HepG2/STAT3 cells were treated with the indicated concentrations of bigelovin for $6 \mathrm{~h}$. Cell viability was determined by MTT assay. (D) HeLa cells were pretreated with bigelovin at the indicated concentrations for $1 \mathrm{~h}$ before IL- 6 stimulation $(10 \mathrm{ng} / \mathrm{mL})$ for $15 \mathrm{~min}$. Whole-cell lysates were processed for Western blot analysis and probed with the indicated antibodies. Tubulin served as a loading control. (E) HeLa cells were pretreated with $10 \mu \mathrm{mol} / \mathrm{L}$ bigelovin for various lengths of time (0-120 min) before stimulation with IL-6 $(10 \mathrm{ng} / \mathrm{mL})$ for $10 \mathrm{~min}$. Whole-cell lysates were subjected to Western blot analysis. (F) MDA-MB-468 and A549 cells were treated with bigelovin at the indicated concentrations for $1 \mathrm{~h}$. Whole-cell lysates were subjected to Western blot analysis.

tion and proceeds to phosphorylate GP130 and STAT3, resulting in the activation of downstream signaling events.

Upon the analysis of the effects of bigelovin on JAK2, it was found that the phosphorylation of JAK2 induced by IL-6 was suppressed by bigelovin (Figure 2A), indicating that the activation of JAK2 was inhibited. Bigelovin also significantly inhibited the phosphorylation of JAK2 in both HeLa and A549 cells without IL-6 stimulation, further supporting the notion that JAK2 might be the direct target of bigelovin (Figure 2B and 2C). We next examined the effects of bigelovin on GP130 and found that bigelovin also inhibited the IL-6-induced phosphorylation of GP130 as expected (Figure 2D). To exclude the possibility of inhibition of the ligand and receptor binding or protein-protein interactions, both of which could lead to JAK2 inactivation, we examined whether bigelovin could disrupt the binding of IL- 6 to its receptors using flow cytometric analysis (Figure 2E). The results indicated that bigelovin did not inhibit the binding of IL-6 to its receptors at a concentration of $100 \mu \mathrm{mol} / \mathrm{L}$. We next examined the effects of bigelovin on the interactions between GP130 and JAK2 (Figure 2F). The coimmunoprecipitation experiments also showed no interference of bigelovin with the interaction between GP130 and JAK2.

To determine whether bigelovin interacts with JAK2 directly, we examined the effects of bigelovin on JAK2 enzymatic activity in vitro (Figure 2G). Our results demonstrated that bigelovin inhibited JAK2 activity with an $\mathrm{IC}_{50}$ of 44.24 
A

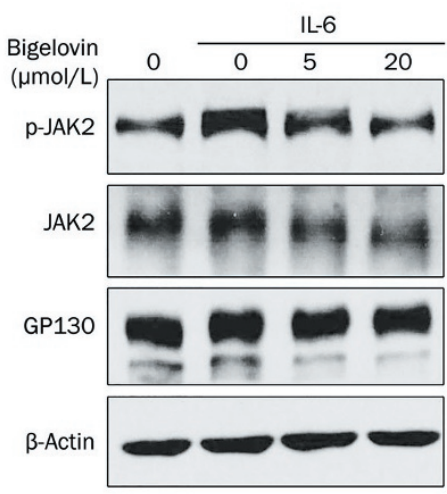

C

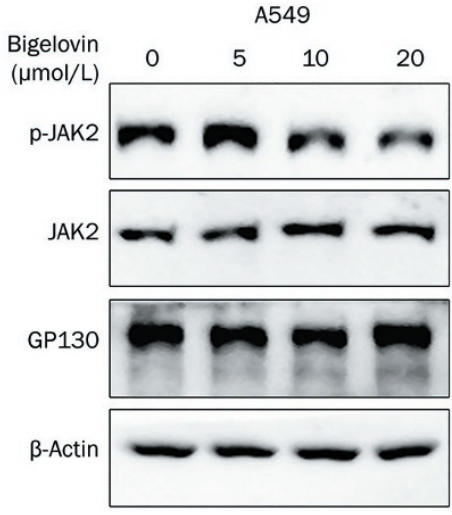

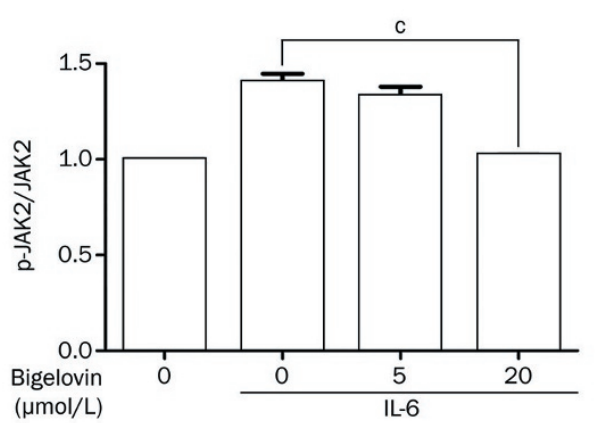

D

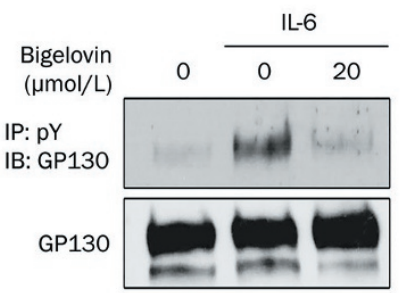

B

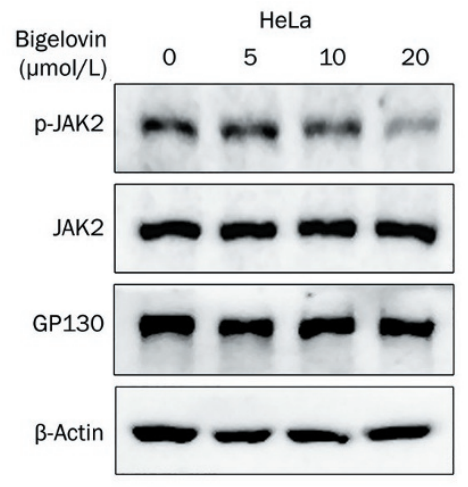

$\mathrm{F}$

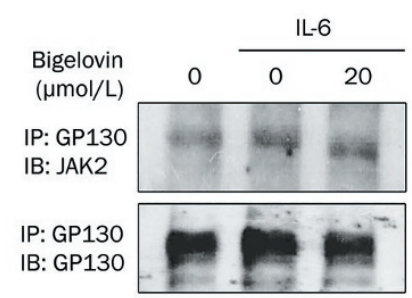

E

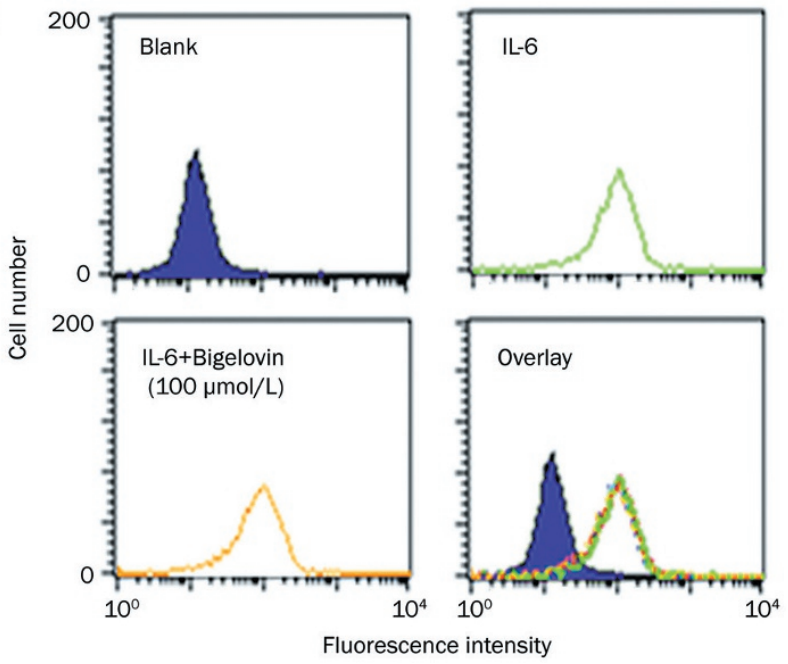

G

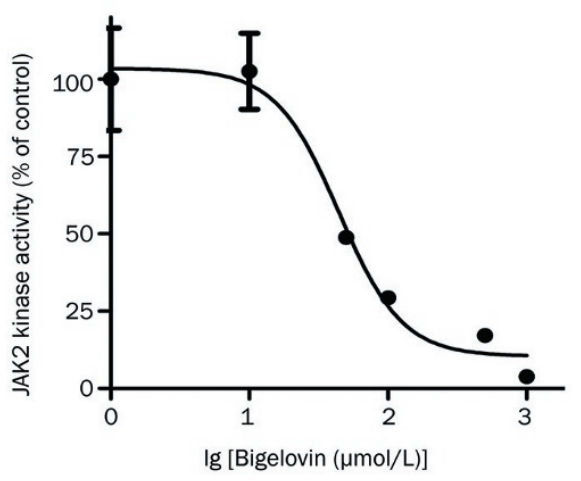

Figure 2. Bigelovin inhibited the JAK2/STAT3 pathway by inactivating JAK2. (A) HeLa cells were pretreated with bigelovin for $1 \mathrm{~h}$ before stimulation with IL-6 $(10 \mathrm{ng} / \mathrm{mL})$ for $15 \mathrm{~min}$. Whole-cell lysates were processed for Western blot analysis with the indicated antibodies. Relative band intensity was normalized for JAK2 and expressed as a percentage compared with the value of untreated control. $n=3$ experiments. Mean \pm SEM. ${ }^{c} P<0.01 \mathrm{vs}$ control. (B) HeLa cells were pretreated with bigelovin for $2 \mathrm{~h}$. Whole-cell lysates were processed for Western blot analysis with the indicated antibodies. (C) A549 cells were pretreated with bigelovin for $1 \mathrm{~h}$. Whole-cell lysates were processed for Western blot analysis with the indicated antibodies. (D) HeLa cells were pretreated with bigelovin for $1 \mathrm{~h}$ before IL-6 stimulation $(10 \mathrm{ng} / \mathrm{mL})$ for $15 \mathrm{~min}$. Next, the cells were harvested for immunoprecipitation with an anti-phosphotyrosine antibody and probed with an anti-GP130 antibody to show the level of phosphorylated GP130. (E) Suspended HeLa cells were pretreated with vehicle or $100 \mu \mathrm{mol} / \mathrm{L}$ bigelovin for $10 \mathrm{~min}$, incubated with biotin-IL-6 (10 ng/mL) for $1 \mathrm{~h}$ at $4{ }^{\circ} \mathrm{C}$, and then incubated with avidin-FITC for $30 \mathrm{~min}$ at $4{ }^{\circ} \mathrm{C}$ followed by flow cytometric analysis. (F) HeLa cells were pretreated with bigelovin for $1 \mathrm{~h}$ before IL-6 stimulation (10 ng/mL) for 15 $\mathrm{min}$, then the cells were harvested for co-immunoprecipitation to show interactions between GP130 and JAK2. (G) In vitro kinase assay of JAK2. The JAK2 proteins immunoprecipitated from the HEK293 cells overexpressing JAK2 were subjected to an in vitro kinase assay in the presence of various concentrations of bigelovin. 
$\mu \mathrm{mol} / \mathrm{L}$ in vitro. Taken together, these data strongly suggested that bigelovin inhibited the JAK2/STAT3 signaling pathway by directly inactivating JAK2.

\section{Bigelovin inhibited JAK/STAT3 signaling in a thiol-dependent} manner

Bigelovin contains an $\alpha, \beta$-unsaturated carbonyl group and an a-alkene- $\gamma$-lactone, which are reactive with thiols. Previous studies have shown that covalent modification of certain cysteine thiol groups of JAK2 by small molecule compounds could lead to JAK2 inactivation ${ }^{[31,32]}$. Therefore, we speculated that bigelovin may react with thiols of the cysteines in the JAK2 protein. If so, other thiol-containing reagents may compete with the cysteines of JAK2 for bigelovin and alleviate the inhibitory effects of bigelovin on JAK2. To test this hypothesis, we preincubated bigelovin with the thiol-contain- ing reagent DTT or reduced glutathione (GSH). As shown in Figure 3A, the inhibition of IL-6-induced STAT3-responsive luciferase reporter activity by bigelovin was abolished by DTT or GSH. Additionally, the inhibitory effects of bigelovin on both IL-6-induced and constitutively activated STAT3 tyrosine phosphorylation were abrogated in the presence of DTT or GSH (Figure 3B and $3 \mathrm{C}$ ). These results suggested that bigelovin inhibited the JAK2/STAT3 signaling pathway possibly through interacting with the cysteine thiol groups of JAK2, although there was no direct evidence that bigelovin acted directly on the cysteines in JAK2.

To further confirm the bigelovin-thiol interaction, bigelovin was incubated with GSH, and the products were examined using LC-MS. The analysis detected one major component

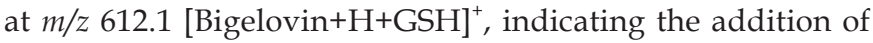
one molecule of GSH to one molecule of bigelovin (Figure

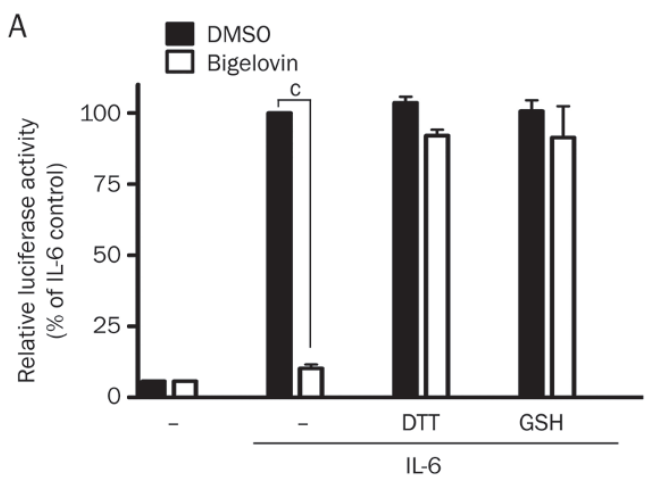

B

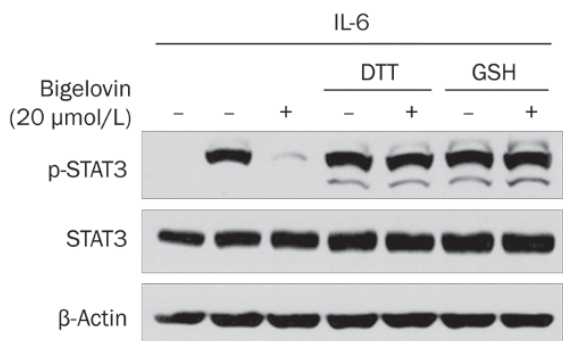

C

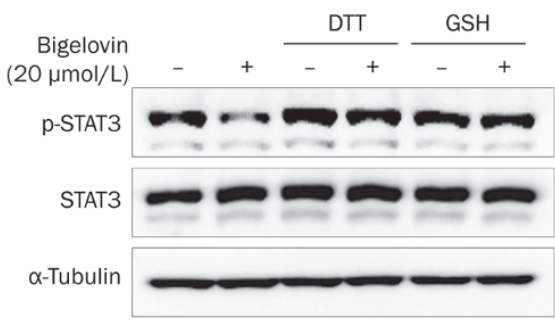

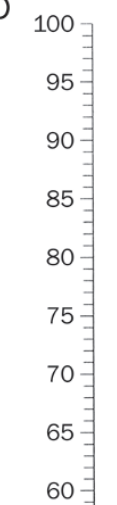

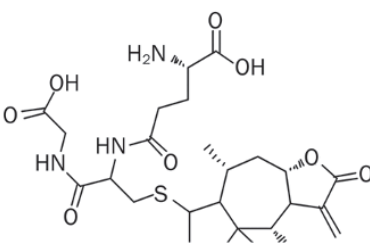

612.1

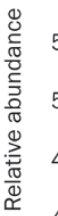

Figure 3. Inhibition of the JAK2/STAT3 signaling pathway by bigelovin is thiol-dependent. (A) HepG2/STAT3 cells were pretreated with DTT (500 $\mu$ mol/L), GSH $(500 \mu \mathrm{mol} / \mathrm{L})$, bigelovin $(20 \mu \mathrm{mol} / \mathrm{L})$, or a mixture for $1 \mathrm{~h}$ and then stimulated with IL-6 $(10 \mathrm{ng} / \mathrm{mL})$ for $5 \mathrm{~h}$. Cells were harvested for luciferase assay. $n=2$ experiments. Mean \pm SEM. ${ }^{\circ} P<0.01$ vs control. (B) HeLa cells were pretreated with DTT (500 $\left.\mu \mathrm{mol} / \mathrm{L}\right), \mathrm{GSH}(500 \mu \mathrm{mol} / \mathrm{L}), \mathrm{bigelovin}(20$ $\mu \mathrm{mol} / \mathrm{L})$, or a mixture for $1 \mathrm{~h}$ and then stimulated with IL-6 $(10 \mathrm{ng} / \mathrm{mL})$ for $10 \mathrm{~min}$. Whole-cell lysates were processed for Western blot analysis using

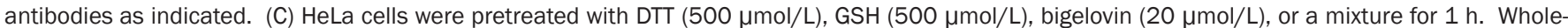
cell lysates were processed for Western blot analysis using antibodies as indicated. (D) Bigelovin was incubated with 4 eq of GSH for $1 \mathrm{~h}$ at $37^{\circ} \mathrm{C}$, and the mixture was resolved by mass spectrometry. Molecular weights of the molecules are indicated. Proposed reaction product is also illustrated. 
A

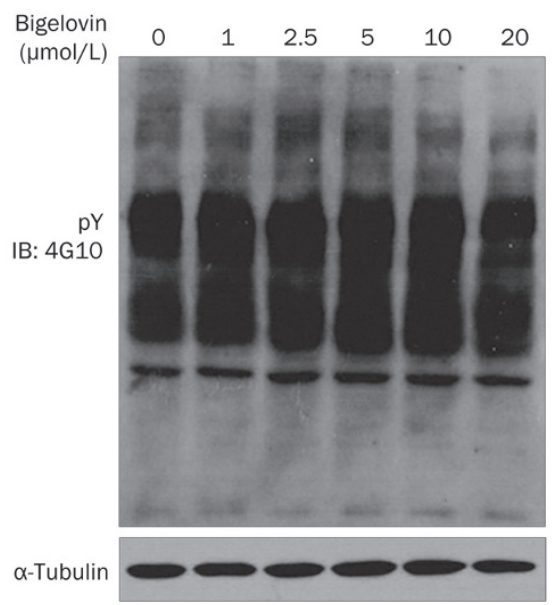

B

\begin{tabular}{lc}
\hline Kinase & Activity of control (\%) \\
\hline JAK2* & 105 \\
EGFR & 99 \\
IGF-1R & 97 \\
Abl & 115 \\
PDGFR $\alpha$ & 99 \\
PI3K & 106 \\
MAPK & 121 \\
IKK $\beta$ & 60 \\
\hline
\end{tabular}

* C-portion of JAK2.
C

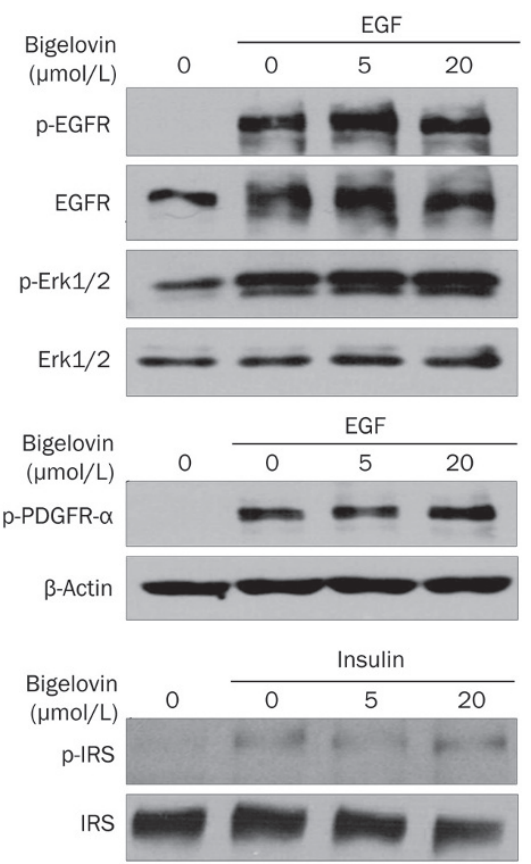

D

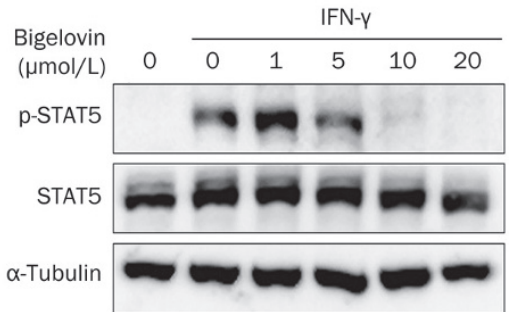

Figure 4. Specificity of bigelovin on JAK2/STAT3 signaling. (A) HeLa cells were treated with bigelovin at the indicated concentrations for $1 \mathrm{~h}$. Then, the cells were lysed for Western blot analysis and probed with anti-tyro-phosphorylation antibody. (B) Effects of $50 \mu \mathrm{mol} / \mathrm{L}$ bigelovin on activities of human kinases. In vitro kinase assays were processed by Millipore Kinase Services. (C) HeLa cells were pretreated with bigelovin at the indicated concentrations for $1 \mathrm{~h}$ and then stimulated with EGF $(100 \mathrm{ng} / \mathrm{mL})$ or Insulin $(100 \mathrm{nmol} / \mathrm{L})$ for $10 \mathrm{~min}$. Cells were harvested for Western blot analysis using the indicated antibodies. (D) HeLa cells were pretreated with bigelovin for $1 \mathrm{~h}$ before stimulation with IFN-y (20 ng/mL) for $15 \mathrm{~min}$. Whole-cell lysates were processed for Western blot analysis with the indicated antibodies. An anti- $\alpha$-tubulin antibody was used as a loading control.

3D). The proposed reaction sites of bigelovin are illustrated in Figure 3D. Taken together, these results provided strong evidence in support of the observation that bigelovin reacts with thiols, which results in the inactivation of JAK2.

\section{The inhibitory effects of bigelovin on the JAK/STAT3 signaling} pathway were relatively specific

To investigate whether the inhibition of the JAK/STAT3 signaling pathway by bigelovin is specific, the effects of bigelovin on the total tyrosine phosphorylation of HeLa cell extracts were analyzed by Western blotting (Figure 4A). No changes in total tyrosine phosphorylation were observed, suggesting that the effects of bigelovin on JAK/STAT3 were not due to the nonspecific inhibition of protein tyrosine phosphorylation.

The effects of bigelovin on a panel of kinases were also analyzed by in vitro kinase assays. At a $50 \mu \mathrm{mol} / \mathrm{L}$ concentration, bigelovin had very few inhibitory effects on all of the kinases analyzed except IKK- $\beta$ (discussed below), confirming the relative specificity of bigelovin towards JAK2 (Figure 4B). Big- elovin did not inhibit the kinase activity of the partial JAK2, which contains only the JAK2 kinase domain (Figure 4B) but inhibited the kinase activity of the full length JAK2 (Figure $2 \mathrm{G})$, suggesting that bigelovin may interact with the nonkinase domain of JAK2.

To further investigate the specificity of bigelovin on signaling pathways, the effects of bigelovin on growth factorinduced receptor phosphorylation, including EGF, PDGF and insulin, were examined. Bigelovin did not affect any of these growth factor-mediated signaling pathways (Figure 4C), again suggesting that bigelovin acted in a relatively specific manner on the JAK2/STAT3 pathway. Because STAT5 is also a substrate of JAK2, we examined the effects of bigelovin on STAT5. As shown in Figure 4D, bigelovin inhibited the phosphorylation of STAT5 as well.

Bigelovin inhibited growth and induced apoptosis of tumor cells The JAK/STAT3 pathway transmits cell survival signals and protects cells from apoptosis ${ }^{[14-21]}$. Therefore, the effects of big- 
A

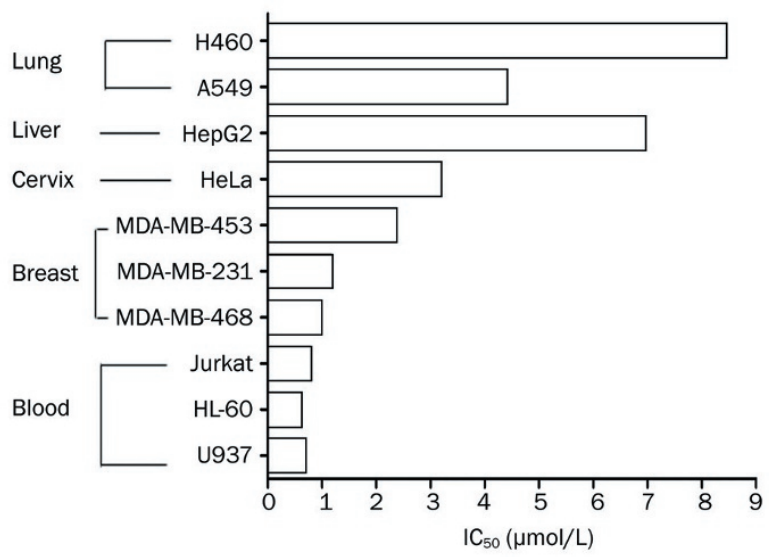

C

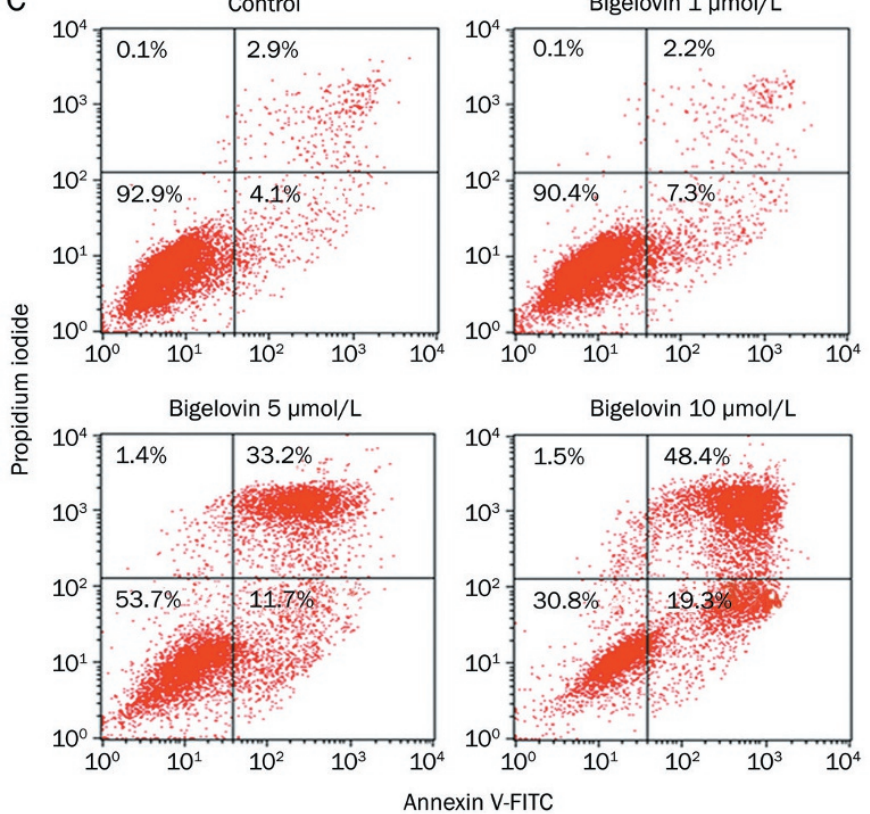

B

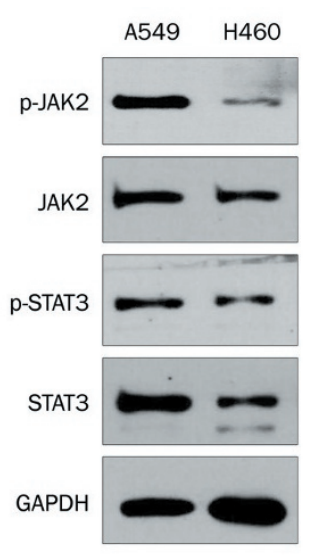

D

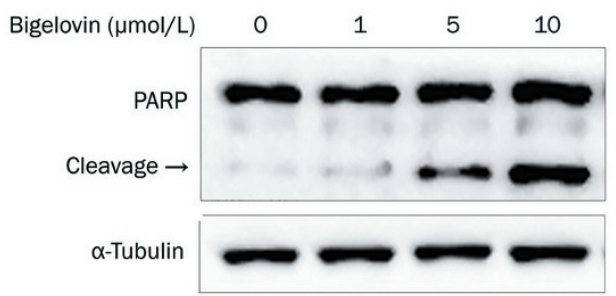

E

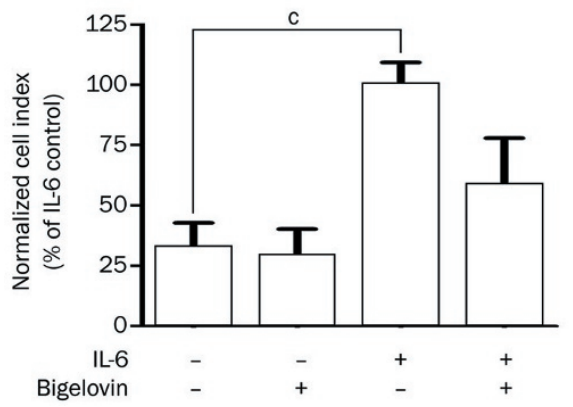

Figure 5. Bigelovin inhibited growth and induced apoptosis of human cancer cells. (A) $I C_{50}$ of bigelovin on the viability of human tumor cell lines. (B) Lysates from two human lung cancer cell lines were processed for Western blot analysis with the indicated antibodies. (C) MDA-MB-468 cells were treated with bigelovin at the indicated concentrations for $22 \mathrm{~h}$. Cells were then stained with Annexin V-FITC and propidium iodide before an analysis of apoptosis by flow cytometry. (D) A549 cells were treated with bigelovin at the indicated concentrations for $24 \mathrm{~h}$ and then harvested for Western blot analysis using an anti-PARP antibody. An anti- $\alpha$-tubulin antibody served as a loading control. (E) HeLa cells were incubated in serum free medium and then treated with bigelovin $(2 \mu \mathrm{mol} / \mathrm{L})$, IL-6 $(100 \mathrm{ng} / \mathrm{mL})$ or IL-6 together with bigelovin $(2 \mu \mathrm{mol} / \mathrm{L})$ for $24 \mathrm{~h}$. Cell growth was measured by a real-time cell analysis (RTCA) system. $n=3$ experiments. Mean \pm SEM. ${ }^{\mathrm{c}} P<0.01$ vs control.

elovin on the growth and survival of a panel of human tumor cell lines from different tissues were examined. Bigelovin inhibited the growth and survival of all the tumor cells tested (Figure 5A). Although the sensitivity of these cell lines to bigelovin treatment varied, leukemia cells seemed to be more sensitive to bigelovin than other cells, which correlated with the fact that JAK2/STAT3 was often constitutively activated in leukemia cells. Additionally, the JAK2 inhibitor, AG490, was first used against leukemia cells ${ }^{[33,34]}$. It was also noticed that the sensitivity of cells to bigelovin treatment varied in cell lines from the same tissue. In three breast cancer cell lines tested, bigelovin induced more death in the MDA-MB-231 and
MDA-MB-468 cells, which had constitutively activated JAK2/ STAT3, than in the MDA-MB-453 cells, which lacked constitutive activation of JAK2/STAT3 ${ }^{[32]}$. Similarly, in the two lung cancer cell lines, bigelovin was more potent in A549 cells, which had a higher level of constitutively activated JAK2/ STAT3 than in H460 cells (Figure 5B).

We further examined whether bigelovin could induce apoptosis in tumor cells. As shown in Figure 5C and 5D, bigelovin induced tumor cell apoptosis, as indicated by the annexin V-positive/PI-negative staining and the induction of PARP cleavage in a concentration-dependent manner.

Because IL- 6 has been reported to induce tumor cell 
growth ${ }^{[35]}$, we analyzed the effect of bigelovin on IL-6 induced cell growth in HeLa cells using a real-time cell analysis (RTCA) system. As shown in Figure 5E, bigelovin inhibited the IL-6-induced growth of HeLa cells.

Taken together, our data demonstrated the potential of bigelovin to inhibit growth and induce apoptosis of human cancer cells, particularly those with constitutively activated STAT3.

\section{Discussion}

The Inula flower has traditionally been used to treat inflammation and cancer in China. However, little was known about how it works. Bigelovin is one of the major sesquiterpene lactones found in the plant. Here, we present evidence that bigelovin is a potent inhibitor of the JAK2/STAT3 signaling pathway. It inhibited constitutive as well as IL-6-induced activation of STAT3 and induced apoptosis in human cancer cells.

We also present evidence that bigelovin inhibited the JAK2/ STAT3 pathway through directly interacting with JAK2, the key kinase of the signaling pathway. Bigelovin appears to inactivate its enzymatic activity. As a consequence, the phosphorylation of both GP130 and STAT3, as well as downstream signaling transduction, were blocked. However, we cannot rule out the possibility that other pathways may also be involved.

Although the detailed mechanisms by which bigelovin interacts with JAK2 remain to be understood, there is some evidence suggesting that bigelovin may form adducts with the thiols of specific cysteines in the JAK2 protein. First, bigelovin contains an $\alpha, \beta$-unsaturated lactone, which is thiol reactive. Second, the LC-MS analysis confirmed that one molecule of GSH was added to one molecule of bigelovin in vitro. Third, DTT treatment abolished the inhibitory effects of bigelovin on JAK2/STAT3 signaling. Although there was no direct evidence that bigelovin acted directly on the cysteines in JAK2, all of these data suggest that bigelovin possibly interacted with JAK2 through a covalent linkage. Interestingly, we found that the reaction requires the conformation of the full-length protein. Bigelovin did not inhibit JAK2 enzymatic activity when incubated with the C-portion of the protein (Figure 4B), which contained the kinase domain of JAK2; it demonstrated inhibitory effects only on the full-length JAK2 (Figure 2G).

The inhibition of bigelovin on JAK2 is relatively specific. It demonstrated very few inhibitory effects on many other kinases we have analyzed except IKK- $\beta$. We infer that the selectivity of bigelovin for target proteins relies, at least in part, on the redox-sensitivity of the target proteins. It has been reported that compounds containing thiol reactive groups, such as arsenic, parthenolide, cyclopentenone prostaglandins, manumycin $\mathrm{A}$, and herbimycin $\mathrm{A}$, could bind directly to IKK- $\beta$ and inhibit IKK- $\beta$ activity ${ }^{[36-40]}$. $C y{ }^{179}$ in the kinase loop, $\mathrm{Cys}^{59}$ near the catalytic site and $\mathrm{Cys}^{662}$ and $\mathrm{Cys}^{716}$ of IKK were reported to be plausible targets of the addition reactions. Our data indicated that the JAKs were additional examples of redox-sensitive proteins. Apart from bigelovin, we also reported that a diterpenoid extracted from the Chinese medicinal herb Euphorbia Fischeriana steud, which contains an a, $\beta$-unsaturated carbonyl group and two epoxy groups, could cross-link JAK proteins and inhibit their enzymatic activity ${ }^{[32]}$. Further studies are needed to identify the possible cysteines involved in the reactions.

It has been reported that bigelovin could also target the NF-KB and RXR pathways and trigger the proteolysis of $\mathrm{E} 2 \mathrm{~F} 1^{[41-43]}$. These targets are all relevant to cancer cell survival and growth. Therefore, the apoptosis of cancer cells induced by bigelovin is probably a result of a combinational effect of all these targets.

In summary, our findings provide the first evidence that bigelovin extracted from the Inula flower is a potent inhibitor of the JAK2/STAT3 signaling pathway. It suppressed both IL6-induced and constitutive STAT3 activation by inactivating JAK2. Moreover, bigelovin is a relatively selective inhibitor of the JAK2/STAT3 signaling pathway. It does not affect growth factor signaling pathways, such as EGFR, PDGFR or IGF-1R. Bigelovin also exhibited strong anticancer activity on a panel of cancer cell lines. Given the importance of the STAT3 signaling pathway in a variety of human cancers, these data strongly support further development of bigelovin as a novel anticancer drug candidate.

\section{Acknowledgements}

This work was supported by the China Ministry of Science and Technology Key New Drug Creation and Manufacturing Program (grant 2013ZX09102015), the China Ministry of Science and Technology Research (grant 2013ZX10002010-009), the National Natural Science Foundation of China (grants 81302792, 81373447, and 91213304), and the China National Key Basic Research Program (grants 2012CB910704 and 2013CB910900).

\section{Author contribution}

Qiang YU, Hao-hao ZHANG and Shan KUANG designed the research; Hao-hao ZHANG and Shan KUANG conducted the experiments; Ying WANG, Xiao-xiao SUN, Yuan GU, Qiang $\mathrm{YU}$ and Li-hong HU contributed reagents or analytic tools; Hao-hao ZHANG, Shan KUANG and Qiang YU analyzed the data; and Hao-hao ZHANG and Qiang YU wrote the manuscript.

\section{References}

1 Zhang T, Xiao W, Gong T, Yang Y, Chen RY, Yu DQ. Two new eudesmanolides from Inula racemosa. J Asian Nat Prod Res 2010; 12 : 788-92.

2 Whan HJ, Gon LB, Kee KY, Woo YJ, Kyoung JH, Hong S, et al. Ergolide, sesquiterpene lactone from Inula britannica, inhibits inducible nitric oxide synthase and cyclo-oxygenase-2 expression in RAW 264.7 macrophages through the inactivation of NF-kappaB. Br J Pharmacol 2001; 133: 503-12.

3 Shan JJ, Yang M, Ren JW. Anti-diabetic and hypolipidemic effects of aqueous-extract from the flower of Inula japonica in alloxan-induced diabetic mice. Biol Pharm Bull 2006; 29: 455-9.

4 Wang Q, Zhou BN, Zhang RW, Lin YY, Lin LZ, Gil RR, et al. Cytotoxicity and NMR spectral assignments of ergolide and bigelovin. Planta Med 
1996; 62: 166-8.

5 Zeng GZ, Tan NH, Ji CJ, Fan JT, Huang HQ, Han HJ, et al. Apoptosis inducement of bigelovin from Inula helianthus-aquatica on human leukemia U937 cells. Phytother Res 2009; 23: 885-91.

6 Schindler C, Levy DE, Decker T. JAK-STAT signaling: from interferons to cytokines. J Biol Chem 2007; 282: 20059-63.

7 Rane SG, Reddy EP. Janus kinases: components of multiple signaling pathways. Oncogene 2000; 19: 5662-79.

8 Darnell JE Jr. Transcription factors as targets for cancer therapy. Nat Rev Cancer 2002; 2: 740-9.

9 Knoops L, Hornakova T, Royer Y, Constantinescu SN, Renauld JC. JAK kinases overexpression promotes in vitro cell transformation. Oncogene 2008; 27: 1511-9.

10 Aaronson DS, Horvath CM. A road map for those who don't know JAKSTAT. Science 2002; 296: 1653-5.

11 Bowman T, Garcia R, Turkson J, Jove R. STATs in oncogenesis. Oncogene 2000; 19: 2474-88.

12 Wang T, Niu G, Kortylewski M, Burdelya L, Shain K, Zhang S, et al. Regulation of the innate and adaptive immune responses by Stat-3 signaling in tumor cells. Nat Med 2004; 10: 48-54.

13 Bromberg JF, Wrzeszczynska MH, Devgan G, Zhao Y, Pestell RG, Albanese C, et al. Stat3 as an oncogene. Cell 1999; 98: 295-303.

14 Yeh HH, Lai WW, Chen HH, Liu HS, Su WC. Autocrine IL-6-induced Stat3 activation contributes to the pathogenesis of lung adenocarcinoma and malignant pleural effusion. Oncogene 2006; 25 : 4300-9.

15 Nagel-Wolfrum K, Buerger C, Wittig I, Butz K, Hoppe-Seyler F, Groner $B$. The interaction of specific peptide aptamers with the DNA binding domain and the dimerization domain of the transcription factor Stat3 inhibits transactivation and induces apoptosis in tumor cells. Mol Cancer Res 2004; 2: 170-82.

16 Sriuranpong V, Park JI, Amornphimoltham P, Patel V, Nelkin BD, Gutkind JS. Epidermal growth factor receptor-independent constitutive activation of STAT3 in head and neck squamous cell carcinoma is mediated by the autocrine/paracrine stimulation of the interleukin 6/ gp130 cytokine system. Cancer Res 2003; 63: 2948-56.

17 Niu G, Wright KL, Huang M, Song L, Haura E, Turkson J, et al. Constitutive Stat3 activity up-regulates VEGF expression and tumor angiogenesis. Oncogene 2002; 21: 2000-8.

18 Spiekermann K, Biethahn S, Wilde S, Hiddemann W, Alves F. Constitutive activation of STAT transcription factors in acute myelogenous leukemia. Eur J Haematol 2001; 67: 63-71.

19 Garcia R, Bowman TL, Niu G, Yu H, Minton S, Muro-Cacho CA, et al. Constitutive activation of Stat3 by the Src and JAK tyrosine kinases participates in growth regulation of human breast carcinoma cells. Oncogene 2001; 20: 2499-513.

20 Lou W, Ni Z, Dyer K, Tweardy DJ, Gao AC. Interleukin-6 induces prostate cancer cell growth accompanied by activation of stat3 signaling pathway. Prostate 2000; 42: 239-42.

21 Catlett-Falcone R, Landowski TH, Oshiro MM, Turkson J, Levitzki A, Savino R, et al. Constitutive activation of Stat3 signaling confers resistance to apoptosis in human U266 myeloma cells. Immunity 1999; 10: 105-15.

22 Levine RL, Pardanani A, Tefferi A, Gilliland DG. Role of JAK2 in the pathogenesis and therapy of myeloproliferative disorders. Nat Rev Cancer 2007; 7: 673-83.

23 Griesinger F, Hennig H, Hillmer F, Podleschny M, Steffens R, Pies A, et al. A BCR-JAK2 fusion gene as the result of a $t(9 ; 22)(p 24 ; q 11.2)$ translocation in a patient with a clinically typical chronic myeloid leukemia. Genes Chromosomes Cancer 2005; 44: 329-33.

24 Murati A, Gelsi-Boyer V, Adélaïde J, Perot C, Talmant P, Giraudier S, et al. PCM1-JAK2 fusion in myeloproliferative disorders and acute erythroid leukemia with $\mathrm{t}(8 ; 9)$ translocation. Leukemia 2005; 19 : 1692-6.
25 Lacronique V, Boureux A, Valle VD, Poirel H, Quang CT, Mauchauffé $\mathrm{M}$, et al. A TEL-JAK2 fusion protein with constitutive kinase activity in human leukemia. Science 1997; 278: 1309-12.

26 James C, Ugo V, Le Couédic JP, Staerk J, Delhommeau F, Lacout C, et al. A unique clonal JAK2 mutation leading to constitutive signalling causes polycythaemia vera. Nature 2005; 434: 1144-8.

27 Levine RL, Wadleigh M, Cools J, Ebert BL, Wernig G, Huntly BJ, et al. Activating mutation in the tyrosine kinase JAK2 in polycythemia vera, essential thrombocythemia, and myeloid metaplasia with myelofibrosis. Cancer Cell 2005; 7: 387-97.

28 Baxter EJ, Scott LM, Campbell PJ, East C, Fourouclas N, Swanton $\mathrm{S}$, et al. Acquired mutation of the tyrosine kinase JAK2 in human myeloproliferative disorders. Lancet 2005; 365: 1054-61.

29 Song L, Turkson J, Karras JG, Jove R, Haura EB. Activation of Stat3 by receptor tyrosine kinases and cytokines regulates survival in human non-small cell carcinoma cells. Oncogene 2003; 22: 4150-65.

30 Gritsko T, Williams A, Turkson J, Kaneko S, Bowman T, Huang M, et al. Persistent activation of stat3 signaling induces survivin gene expression and confers resistance to apoptosis in human breast cancer cells. Clin Cancer Res 2006; 12: 11-9.

31 Duhé RJ, Evans GA, Erwin RA, Kirken RA, Cox GW, Farrar WL. Nitric oxide and thiol redox regulation of Janus kinase activity. Proc Natl Acad Sci U S A 1998; 95: 126-31.

32 Wang Y, Ma X, Yan S, Shen S, Zhu H, Gu Y, et al. 17-Hydroxy-jolkinolide $B$ inhibits signal transducers and activators of transcription 3 signaling by covalently cross-linking Janus kinases and induces apoptosis of human cancer cells. Cancer Res 2009; 69: 7302-10.

33 Bromberg J. Stat proteins and oncogenesis. Clinical Invest 2002; 109: 1139-42.

34 Meydan N, Grunberger T, Dadi H, Shahar M, Arpaia E, Lapidot Z, et al. Inhibition of acute lymphoblastic leukaemia by a Jak-2 inhibitor. Nature 1996; 379: 645-8.

35 Miki S, Iwano M, Miki Y, Yamamoto M, Tang B, Yokokawa K, et al. Interleukin-6 (IL-6) functions as an in vitro autocrine growth factor in renal cell carcinomas. FEBS Letters 1989; 250: 607-10.

36 Roussel RR, Barchowsky A. Arsenic inhibits NF-kappaB-mediated gene transcription by blocking IkappaB kinase activity and IkappaBalpha phosphorylation and degradation. Arch Biochem Biophys 2000; 377: 204-12.

37 Rossi A, Kapahi P, Natoli G, Takahashi T, Chen Y, Karin M, et al. Antiinflammatory cyclopentenone prostaglandins are direct inhibitors of IkappaB kinase. Nature 2000; 403: 103-8.

38 Kwok BH, Koh B, Ndubuisi MI, Elofsson M, Crews CM. The antiinflammatory natural product parthenolide from the medicinal herb Feverfew directly binds to and inhibits IkappaB kinase. Chem Biol 2001; 8: 759-66.

39 Bernier M, Kwon YK, Pandey SK, Zhu TN, Zhao RJ, Maciuk A, et al. Binding of manumycin A inhibits IkappaB kinase beta activity. J Biol Chem 2006; 281: 2551-61.

40 Ogino S, Tsuruma K, Uehara T, Nomura Y. Herbimycin A abrogates nuclear factor-kappaB activation by interacting preferentially with the IkappaB kinase beta subunit. Mol Pharmacol 2004; 65: 1344-51.

41 Nam KW, Oh GT, Seo EK, Kim KH, Koo U, Lee SJ, et al. Nuclear factor kappaB- mediated down-regulation of adhesion molecules: possible mechanism for inhibitory activity of bigelovin against inflammatory monocytes adhesion to endothelial cells. J Ethnopharmacol 2009; 123: 250-6.

42 Zhang H, Li L, Chen L, Hu L, Jiang H, Shen X. Structure basis of bigelovin as a selective RXR agonist with a distinct binding mode. J Mol Biol 2011; 407: 13-20.

43 Liu JL, Zeng GZ, Liu XL, Liu YQ, Hu ZG, Liu Y, et al. Small compound bigelovin exerts inhibitory effects and triggers proteolysis of E2F1 in multiple myeloma cells. Cancer Sci 2013; 104: 1697-704. 